\title{
JBIR-69, a new metabolite from Streptomyces sp. OG05
}

\author{
Takeshi Fujiwara $^{1}$, Aya Nagai ${ }^{1}$, Motoki Takagi ${ }^{1}$ and Kazuo Shin-ya ${ }^{2}$
}

The Journal of Antibiotics (2010) 63, 95-96; doi:10.1038/ja.2009.132; published online 15 January 2010

Keywords: cytotoxicity; HL-60; Streptomyces; thioester

Actinobacteria have been extensively studied thus far, and they are known to produce pharmaceutically important compounds. ${ }^{1,2}$ Soil serves as the primary source of actinobacteria and, therefore, we attempted to obtain novel metabolites from actinobacteria isolated from soil samples. During our screening program for novel metabolites, a new metabolite possessing a thioester named JBIR-69 (1, Figure 1a), together with a known compound, 3-isopropylmalate methyl ester, was isolated from the culture broth of Streptomyces sp. OG05. This paper describes the fermentation, isolation, structural elucidation, and, in brief, the biological activity of $\mathbf{1}$.

Streptomyces sp. OG05 was isolated from a soil sample collected in Okinawa Prefecture, Japan, and was cultured on a rotary shaker (180 r.p.m.) at $27^{\circ} \mathrm{C}$ for 5 days in 500 -ml Erlenmeyer flasks containing $100 \mathrm{ml}$ of $2 \%$ glycerol (Nacalai Tesque, Kyoto, Japan), 1\% molasses (Dai-Nippon Meiji Sugar, Tokyo, Japan), 0.5\% casein (Kanto Chemical, Tokyo, Japan), $0.1 \%$ polypeptone (Nihon Pharmaceutical, Tokyo, Japan), and $0.4 \% \mathrm{CaCO}_{3}$ (Kozaki Pharmaceutical, Tokyo, Japan; $\mathrm{pH}$ 7.2 before sterilization).

The mycelium collected from the culture broth (11) by centrifugation was extracted with $\mathrm{Me}_{2} \mathrm{CO}(200 \mathrm{ml})$. After concentration in vacuo, the residue aqueous concentrate with $\mathrm{pH}$ adjusted to 2-3 using $2 \mathrm{~N} \mathrm{HCl}$ was extracted twice with EtOAc. The organic layer was dried over anhydrous $\mathrm{Na}_{2} \mathrm{SO}_{4}$ and concentrated in vacuo. The dried residue $(180 \mathrm{mg})$ was subjected to normal-phase medium-pressure liquid chromatography (Purif-Pack SI-60, size: 20, Moritex, Tokyo, Japan) with a Hexane-EtOAc (0-30\% EtOAc) linear gradient system, followed by elution with a $\mathrm{CHCl}_{3}-\mathrm{MeOH}(0-90 \% \mathrm{MeOH})$ linear gradient system; then, peak detection was carried out with UV absorption at $254 \mathrm{~nm}$. The $10-20 \% \mathrm{MeOH}$ elute fractions $(30 \mathrm{mg}$ ) were further purified by reversed-phase high-pressure liquid chromatography (HPLC) using a PEGASIL ODS column (Senshu Pak, 20 i.d. $\times 150 \mathrm{~mm}$, Senshu Scientific, Tokyo, Japan) with a $\mathrm{H}_{2} \mathrm{O}-\mathrm{MeOH}$ $(0-100 \% \mathrm{MeOH})$ linear gradient system containing $0.1 \%$ formic acid to yield JBIR-69 $(1,15 \mathrm{mg})$ together with 3-isopropylmalate methyl ester $(6 \mathrm{mg}) .^{3}$

Compound 1 was obtained as a colorless oil $\left([\alpha]_{D}-11.8,29^{\circ} \mathrm{C}\right.$, c $0.28\left(\mathrm{CHCl}_{3}\right), \mathrm{UV}(\mathrm{MeOH}) \lambda_{\max }(\varepsilon) 233$ (15 800)). The infrared (IR) spectrum $(\mathrm{KBr})$ of 1 revealed the characteristic absorptions of esters $\left(v_{\max } 1730 \mathrm{~cm}^{-1}\right)$, amide $\left(v_{\max } 1670 \mathrm{~cm}^{-1}\right)$, hydroxyl, and/or amide $\mathrm{NH}\left(v_{\max } 3400 \mathrm{~cm}^{-1}\right)$ groups. Its molecular formula was established as $\mathrm{C}_{13} \mathrm{H}_{21} \mathrm{NO}_{7} \mathrm{~S}\left(\mathrm{~m} / z[\mathrm{M}-\mathrm{H}]^{-} 334.0960,+0.2 \mathrm{mmu}\right)$ by high-resolution electrospray ionization-mass spectrum.

The structure of $\mathbf{1}$ was mainly elucidated by the analyses of NMR spectra, including heteronuclear single-quantum coherence, doublequantum-filtered correlation (DQF-COSY), and constant-time heteronuclear multiple-bond correlation (HMBC). ${ }^{4}$ The ${ }^{1} \mathrm{H}$ and ${ }^{13} \mathrm{C}$ NMR spectral data revealed by the heteronuclear multiple quantum coherence spectrum for $\mathbf{1}$ are listed in Table 1. The DQF-COSY and HMBC analyses revealed the two partial structures (Figure 1b). The sequence from an amide proton $2-\mathrm{NH}\left(\delta_{\mathrm{H}} 6.68\right)$ to methylene protons $3-\mathrm{H}\left(\delta_{\mathrm{H}}\right.$ 3.67 and 3.22) through an $\alpha$-methine proton $2-\mathrm{H}\left(\delta_{\mathrm{H}} 4.91, \delta_{\mathrm{C}} 52.2\right)$ was observed in the DQF-COSY of 1 . In the HMBC spectrum, ${ }^{1} \mathrm{H}-{ }^{13} \mathrm{C}$ longrange couplings from the $\alpha$-methine proton $2-\mathrm{H}$ and the methylene protons $3-\mathrm{H}$ to a carbonyl carbon $\mathrm{C}-1\left(\delta_{\mathrm{C}} 171.6\right)$, and from the amide proton $2-\mathrm{NH}$ and a singlet methyl proton $10-\mathrm{H}\left(\delta_{\mathrm{H}} 2.12\right)$ to an amide carbonyl carbon C-9 $\left(\delta_{\mathrm{C}} 172.4\right)$ were observed. Thus, the carbonyl and acetyl moieties were elucidated to be substituted at the C-2 and 2-N positions, respectively. In a similar manner, the sequence from an oxymethine proton $6-\mathrm{H}\left(\delta_{\mathrm{H}} 4.46\right)$ to a methyl proton $12-\mathrm{H}\left(\delta_{\mathrm{H}} 0.96\right)$ through methine protons $5-\mathrm{H}\left(\delta_{\mathrm{H}} 2.64\right)$ and $11-\mathrm{H}\left(\delta_{\mathrm{H}} 2.30\right)$, which in turn spin coupled to a methyl proton $13-\mathrm{H}\left(\delta_{\mathrm{H}} 1.06\right)$, was established. ${ }^{1} \mathrm{H}-{ }^{13} \mathrm{C}$ long-range couplings from $5-\mathrm{H}$ and $11-\mathrm{H}$ to a carbonyl carbon C-4 $\left(\delta_{\mathrm{C}} 200.3\right)$ and from $5-\mathrm{H}$ and $6-\mathrm{H}$ to an ester carbonyl carbon $\mathrm{C}-7$ $\left(\delta_{\mathrm{C}} 174.7\right)$ were recognized in the HMBC spectrum of 1 . A methoxyl proton $8-\mathrm{H}\left(\delta_{\mathrm{H}} 3.81\right)$ was long-range coupled to the ester carbonyl carbon C-7, which established the substitution position of the methoxyl

${ }^{1}$ Biomedicinal Information Research Center (BIRC), Japan Biological Informatics Consortium (JBIC), Koto-ku, Tokyo, Japan and ${ }^{2}$ Biomedicinal Information Research Center (BIRC), National Institute of Advanced Industrial Science and Technology (AIST), Koto-ku, Tokyo, Japan

Correspondence: Dr M Takagi, Biomedicinal Information Research Centre (BIRC), Japan Biological Informatics Consortium (JBIC), 2-4-7 Aomi, Koto-ku, Tokyo 135-0064, Japan or Dr K Shin-ya, Biomedicinal Information Research Center (BIRC), National Institute of Advanced Industrial Science and Technology (AIST), 2-4-7 Aomi, Koto-ku, Tokyo 135-0064, Japan.

E-mails: motoki-takagi@aist.go.jp or k-shinya@aist.go.jp

Received 7 November 2009; revised 9 December 2009; accepted 14 December 2009; published online 15 January 2010 
a<smiles>COC(=O)[C@H](O)[C@H](C(=O)SC[C@H](NC(C)=O)C(=O)O)C(C)C</smiles>

b

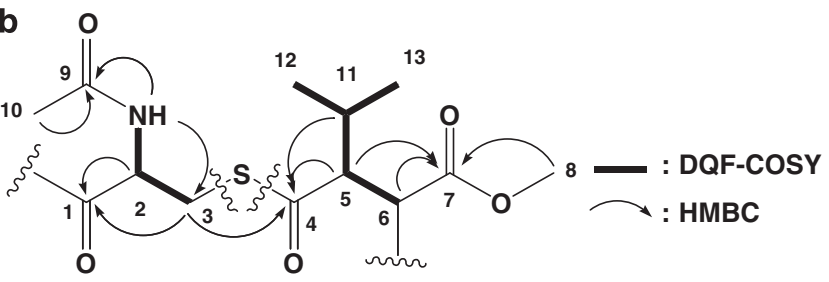

Figure 1 (a) Structure of 1 . (b) Key correlations in the DQF-COSY (bold line) and $\mathrm{HMBC}$ (arrow) spectra of 1 .

Table $1^{1} \mathrm{H}$ and ${ }^{13} \mathrm{C}$ NMR spectral data for 1 and 3-isopropylmalate methyl ester

\begin{tabular}{|c|c|c|c|c|}
\hline \multirow[b]{2}{*}{ No. } & \multicolumn{2}{|r|}{1} & \multicolumn{2}{|c|}{ 3-Isopropylmalate methyl ester } \\
\hline & ${ }^{13} \mathrm{C}$ & ${ }^{1} \mathrm{H}(\mathrm{J}$ in $\mathrm{Hz})$ & ${ }^{13} \mathrm{C}$ & ${ }^{1} \mathrm{H}(\mathrm{J}$ in $\mathrm{Hz})$ \\
\hline 1 & 171.6 & & & \\
\hline 2 & 52.2 & $4.91(1 \mathrm{H}, \mathrm{m})$ & & \\
\hline 3 & 29.7 & $3.22(1 \mathrm{H}, \mathrm{dd}, 14.5,4.4)$ & & \\
\hline & & $3.67(1 \mathrm{H}, \mathrm{dd}, 14.5,3.9)$ & & \\
\hline 4 & 200.3 & & 177.7 & \\
\hline 5 & 63.9 & $2.64(1 \mathrm{H}, \mathrm{dd}, 10.1,2.9)$ & 55.8 & $2.67(1 \mathrm{H}, \mathrm{dd}, 9.9,2.8)$ \\
\hline 6 & 70.1 & $4.46(1 \mathrm{H}, \mathrm{d}, 3.1)$ & 69.7 & $4.50(1 \mathrm{H}, \mathrm{d}, 2.9)$ \\
\hline 7 & 174.7 & & 174.0 & \\
\hline 8 & 52.9 & $3.81(3 \mathrm{H}, \mathrm{s})$ & 52.2 & $3.82(3 \mathrm{H}, \mathrm{s})$ \\
\hline 9 & 172.4 & & & \\
\hline 10 & 22.5 & $2.12(3 \mathrm{H}, \mathrm{s})$ & & \\
\hline 11 & 27.5 & $2.30(1 \mathrm{H}, \mathrm{m})$ & 26.9 & $2.27(1 \mathrm{H}, \mathrm{m})$ \\
\hline 12 & 20.9 & $0.96(3 \mathrm{H}, \mathrm{d}, 6.6)$ & 20.9 & $1.06(3 \mathrm{H}, \mathrm{d}, 6.4)$ \\
\hline 13 & 19.9 & $1.06(3 \mathrm{H}, \mathrm{d}, 6.6)$ & 19.8 & $1.03(3 \mathrm{H}, \mathrm{d}, 6.4)$ \\
\hline $\mathrm{NH}$ & & $6.68(1 \mathrm{H}, \mathrm{d}, 6.6)$ & & \\
\hline
\end{tabular}

${ }^{13} \mathrm{C}(125 \mathrm{MHz})$ and ${ }^{1} \mathrm{H}(500 \mathrm{MHz})$ NMR spectra were obtained using an NMR System $500 \mathrm{NB}$ $\mathrm{CL}$ (Varian, Palo Alto, $\mathrm{CA}, \mathrm{USA}$ ) in $\mathrm{CDCl}_{3}$, and the solvent peak was used as an internal standard $\left(\delta_{\mathrm{C}} 77.0, \delta_{\mathrm{H}} 7.24\right)$.

functional group. By taking into consideration the molecular formula of 1 and the long-range coupling from $3-\mathrm{H}$ to $\mathrm{C}-4$, together with the ${ }^{13} \mathrm{C}$ chemical shifts of C-3 $\left(\delta_{\mathrm{C}} 29.7\right)$ and C-4, these partial structures should be connected through a sulfur atom. Finally, the structure of 1 was determined to be 2-acetamido-3-(3-hydroxy-2-isopropyl-4-methoxy-4oxobutanoylthio)propanoic acid, as shown in Figure 1. This structure was also supported by alkaline hydrolysis $\left(2 \mathrm{~N} \mathrm{NaOH}, 40^{\circ} \mathrm{C}, 1 \mathrm{~h}\right)$, which yielded an $\mathrm{N}$-acetyl cystein and 2-hydroxy-3-isopropylsuccinic acid residues.

The absolute stereochemistry of $\mathbf{1}$ was established as follows. The $\mathrm{N}$-acetyl cystein obtained from 1 by alkaline hydrolysis was determined as $R$ by comparing the optical rotations $\left([\alpha]_{\mathrm{D}} 6.25, c 0.24\right.$ $(\mathrm{MeOH}), 25^{\circ} \mathrm{C}$; authentic sample: $[\alpha]_{\mathrm{D}} 6.08$, c $\left.0.25(\mathrm{MeOH}), 25^{\circ} \mathrm{C}\right)$. The absolute stereochemistry at C-5 and C- 6 was determined by the modified-Mosher method ${ }^{5}$ and the $J$-based method. ${ }^{6-9}$ Compound 1 was treated with trimethylsilyldiazomethane to afford a methyl ester of 1. This methyl ester compound was then reacted with $(R)$ - and $(S)$-MTPA chloride in pyridine. The differences in chemical shift

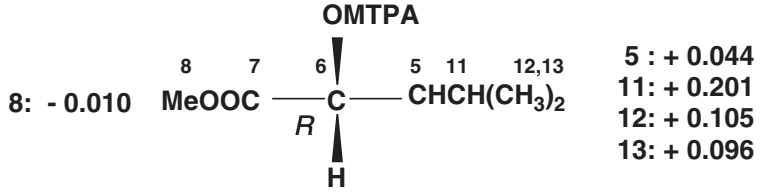

bo
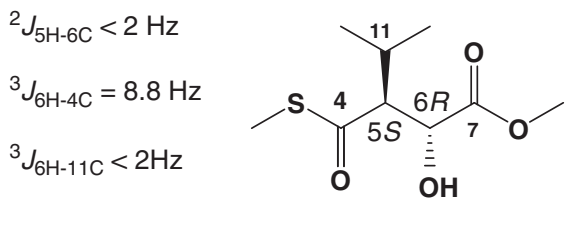

Figure 2 (a) Absolute configuration at C- 6 revealed by modified Mosher's method. (b) Absolute configuration at C-5 established by J-based analysis.

values obtained by subtracting the $(R)$-MTPA ester values from $(S)$-MTPA ester values $(\delta \Delta=\delta(S)$-MTPA $-\delta(R)$-MTPA) are summarized in Figure $2 \mathrm{a}$. From these values, the absolute configuration at C-6 was concluded to be $6 R$. A small coupling constant $(<2 \mathrm{~Hz})$ between $5-\mathrm{H}$ and $\mathrm{C}-6$ revealed that the oxygen atom and $5-\mathrm{H}$ were in an anti relationship. A large coupling constant between $6-\mathrm{H}$ and C-4 $\left({ }^{3} \mathrm{~J}_{\mathrm{H} 6-\mathrm{C} 4}=8.8 \mathrm{~Hz}\right)$ and a small one between $6-\mathrm{H}$ and $\mathrm{C}-11$ $\left({ }^{3} J_{\mathrm{H} 6-\mathrm{C} 11}<2 \mathrm{~Hz}\right)$ indicated that they were in anti and gauche locations, respectively, as shown in Figure $2 \mathrm{~b}$. These results revealed the absolute configuration at C-5 to be $5 S$. Thus, the absolute structure of 1 was established, as shown in Figure 1a.

The cytotoxic activity of $\mathbf{1}$ against human acute myelogenous leukemia HL-60 cells was tested by the WST-8 [2-(2-methoxy-4nitrophenyl)-3-(4-nitrophenyl)-5-(2,4-disulfophenyl)-2H-tetrazolium, monosodium salt] colorimetric assay (Cell Counting Kit, Dojindo, Kumamoto, Japan). It was found that 1 exhibited a weak cytotoxic effect against HL-60 cells for $48 \mathrm{~h}$ with an $\mathrm{IC}_{50}$ value of $210 \mu \mathrm{m}$. We also attempted to investigate the antimicrobial activitiy of $\mathbf{1}$. However, 1 did not exhibit antimicrobial activity against Micrococcus luteus, Escherichia coli, and Schizosaccharomyces pombe.

\section{ACKNOWLEDGEMENTS}

This work was supported in part by the New Energy and Industrial Technology Development Organization of Japan (NEDO) and a Grant-in-Aid for Scientific Research (20380070 to KS) from The Japan Society for the Promotion of Science (JSPS).

1 Berdy, J. Bioactive microbial metabolites-a personal view. J. Antibiot. 58, 1-26 (2005). 2 Demain, A. L. \& Sanchez, S. Microbial drug discovery: 80 years of progress. J. Antibiot. 62, 5-16 (2009).

3 Dumlao, D. S., Hertz, N. \& Claecke, S. Secreted signals invasive growth during amino acid starvation in Saccharomyces cerevisiae. Biochemistry 47, 698-709 (2008).

4 Furihata, K. \& Seto, H. Constant time HMBC (CT-HMBC), a new HMBC technique useful for improving separation of cross peaks. Tetrahedron Lett. 39, 7337-7340 (1998).

5 Ohtani, I., Kusumi, T., Kashman, Y. \& Kakisawa, H. High-field FT NMR application of Mosher method - the absolute-configurations of marine terpenoids. J. Am. Chem. Soc. 113, 4092-4096 (1991).

6 Kobayashi, H., Shin-ya, K., Furihata, K., Hayakawa, Y. \& Seto, H. Absolute configuration of a novel glutamate receptor antagonist kaitocephalin. Tetrahedron Lett. 42, 4021-4023 (2001).

7 Murata, M., Matsuoka, S., Matsumori, N., Paul, G. K. \& Tachibana, K. Absolute configuration of amphidinol 3 , the first complete structure determination from amphidinol homologues: application of a new configuration analysis based on carbon-hydrogen spin-coupling constants. J. Am. Chem. Soc. 121, 870-871 (1999).

8 Park, H. R., Chijiwa, S., Furihata, K., Hayakawa, Y. \& Shin-Ya, K. Relative and absolute configuration of versipelostatin, a down-regulator of molecular chaperone GRP78 expression. Org. Lett. 9, 1457-1460 (2007).

9 Umeda, Y. et al. Absolute structure of prunustatin A, a novel GRP78 molecular chaperone down-regulator. Org. Lett. 9, 4239-4242 (2007). 